\title{
Oral contraceptives and liver function
}

\author{
TOM HARGREAVES \\ From the Area Pathology Laboratory, Heavitree, Exeter, Devon
}

SYNOPSIS Oral contraceptives can cause liver damage and jaundice but this is very rare in women in the United Kingdom. The drugs are contraindicated where there is a history of recurrent intrahepatic cholestasis of pregnancy and acute or chronic disturbance of liver function which can be congenital or acquired. It is not yet known whether the oestrogenic or progestogenic components of oral contraceptives cause the hepatic abnormalities. The available data suggest that neither oestrogens nor progestogens in low doses impair hepatic excretory processes. The full implications of the continued administration of oestrogens and progestogens for many years on liver proteins are not yet known.

The introduction of oestrogens and progestogens as antifertility agents has meant that very large numbers of women are receiving treatment with steroids for many years. It is important that the potential toxicity of these substances should be appreciated. The liver plays a central role in the metabolism of oestrogens and progestogens and it is becoming obvious that these substances can act directly or indirectly on the liver to produce a variety of biological effects which have both physiological and pathological significance.

Most oral contraceptives are offered as combinations of a synthetic oestrogen and progestogen or in a sequential fashion with oestrogen alone during most of the cycle followed by a combination of oestrogen and progestogen during the final five days. Modifications have involved gradual reduction of the amount of progestogen as well as the introduction of new synthetic progestogens. The reduction of the progestogen component means that the oestrogen becomes the major contraceptive factor. The lower doses now given decrease such side effects as headache, weight gain, and nausea. The preparations given in sequential fashion rely on the oestrogen component for their contraceptive action.

One of the difficulties for the non-expert in this field is understanding the nomenclature of the steroids and remembering the trade names involved. Table I gives the names and components of some of the more commonly used oral contraceptives. The structures of these substances is shown in Figure 1.

Several new approaches have been made in this field recently. One of these is the administration of a low daily dosage of an oral progestogen such as $0.5 \mathrm{mg}$ chlormadinone acetate alone. 
<smiles></smiles><smiles>C=CC1(O)CCC2C3CCc4cc(OC)ccc4C3CCC21</smiles><smiles>C#CC1(O)CCC2C3CCC4=CC(=O)CCC4C3CCC21OOCOC</smiles><smiles>C#CC1(OC)CCC2C3CCC4=CC(=O)CCC4C3CCC21</smiles><smiles>C#C[C@]1(O)CCC2C3CCC4=CCCCC4C3CCC21</smiles><smiles>C#CC1(O)CC2C3CCC4=C(CCC(=O)C4)C3CCC21COCOCCO</smiles><smiles>CC(=O)OC1(C)CCC2C3CCC4(CCC(=O)C=C4C)C(C)(OC(C)=O)C3CCC21</smiles><smiles>C#CC1(OC(C)=O)CCC2C3CCC4=CC(OC)CCC4C3CCC21C(C)=O</smiles>

Fig. 1 Structural formulae of certain components of oral contraceptive tablets.

\begin{tabular}{lll}
\hline Name & Progestogen & Oestrogen \\
\hline Anovlar 21 & Norethisterone acetate & Ethynyloestradiol \\
Conovid & Norethynodrel & Mestranol \\
Lyndiol & Lynestrenol & Mestranol \\
Norinyl & Norethisterone & Mestranol \\
Norlestrin & Norethisterone acetate & Ethynyloestradiol \\
Ovulen & Ethynodiol diacetate & Mestranol \\
Volidan & Megestrol acetate & Ethynyloestradiol \\
\hline
\end{tabular}

Table I Commonly used oral contraceptives

The side effects of this regimen (apart from a slightly greater pregnancy risk) have not been assessed as yet.

\section{Effect on the Liver}

In 1962 Perez-Mera and Shields noted jaundice occurring in relation to norethindrone acetate therapy. In the period 1964-65 a series of reports appeared reporting either patients who became jaundiced while on oral contraceptives(Sotaniemi, Kreus, and Scheinin, 1964; Eisalo and Räsänen, 1965; Cullberg, Lundström, and Stenram, 1965;
Larsson-Cohn and Stenram, 1965 ;Baines, $1965 ;$; Elliott and Hendry, 1965) or series of women taking oral contraceptives in whom there was no evidence of liver damage (Swaab, 1964; Swyerô and Little, 1965). In spite of these latter reports it is now clear that there is a relationship betweeno oral contraceptive therapy and liver damage. About 100 cases of jaundice attributable to oralo contraceptive therapy have been published but it $\frac{\overline{\bar{T}}}{5}$. is said that these represent only $10 \%$ of the cases $\stackrel{\odot}{\varnothing}$ reported to the various pharmaceutical companiess (Hartley, Boitnott, and Iber, 1969). Additional ${ }_{-}^{\infty}$ cases are known but have not been reported so? it is difficult to arrive at a true incidence but an $\vec{\omega}$ estimate of one case of jaundice per 10,000 ल women taking oral contraceptives has been sug $-\overline{0}$ gested in the United States (Schaffner, 1966).

There appears to be a wide spectrum of $\dot{\omega}$ hepatic abnormalities that appear with the use -of these drugs. For the purpose of this review we can classify these into (1) abnormalities in non-음 jaundiced women and (2) jaundice in women asso- ciated with oral contraceptives.

\section{HEPATIC ABNORMALITIES WITHOUT} JAUNDICE

Alteration can occur in certain liver tests in. 'normal' women taking oral contraceptives if they are looked for at the correct time. These abnormalities are found during routine screening $\bar{O}$ or investigational programmes of women taking the drugs and may consist of abnormalities of $\stackrel{\mathbb{Q}}{\varrho}$ bromsulphthalein retention, plasma enzyme $\overrightarrow{\vec{A}}$ activity, plasma proteins, or liver histology.

\section{Bromsulphthalein retention}

This has been found in about 10 to $40 \%$ of women taking oral contraceptives although it is usually? not greater than $15 \%$ retention, is often transient $\frac{0}{3}$ and disappears while the woman continues to take the drug (Goldzieher, 1964; Rice-Wray, $\frac{O}{3}$ 1964). In general the larger the dose of the progestogen the more bromsulphthalein is retained $\frac{}{2}$ but in the individual patient increasing the dose $\frac{D}{2}$ will not necessarily increase bromsulphthalein retention (Schaffner, 1966). The increased brom- N sulphthalein retention is associated with a decrease in the maximal transport of bromsulphthalein into the bile but there is no change in the $\omega$ storage capacity for the dye (Kleiner, Kresch, and Arias, 1965).

\section{Aminotransferases}

It has been reported that there is no elevation of 0 plasma aminotransferase levels in women taking $\frac{\vec{\Phi}}{\mathbb{D}}$ oral contraceptives (Swaab, 1964). However, in $\stackrel{\mathbb{P}}{\mathscr{Q}}$ other series levels were raised in 6 to $7 \%$ (Larsson- $\stackrel{\mathbb{Q}}{\varrho}$ Cohn and Stenram, 1965) and in 16 to $18 \%$ (Eisalo, Järvinen, and Luukkainen, 1965) of $\varnothing$ women taking oral contraceptives. The increased serum aminotransferase levels did not parallel the abnormal results found in other tests. The 
level of raised aminotransferase values seems to vary, although in one report from Sweden levels of up to 150 and 430 for the aspartate and alanine aminotransferases respectively were recorded (Borglin, 1965).

The increased aminotransferase levels noted with oral contraceptive administration often disappear within one month of therapy (Schaffner, 1966) so their recognition may require determinations to be made frequently in the early stage of administration. Larsson-Cohn (1966) noted that there was an increased incidence of abnormal aminotransferase values towards the latter part of each menstrual cycle and that the abnormalities were more frequent during the early months of taking oral contraceptives. These values returned to normal during continued administration of the drugs. Failure to do these tests frequently or to do them too long after beginning therapy may be the cause of the previous negative reports (Swaab, 1964; Swyer and Little, 1965). That this reaction occurs at all with the antifertility drugs and is more severe when the patient is jaundiced suggests that cellular organelles have been disorganized to some extent. This must be considered an undesirable change, although nothing is usually seen on electron microscopy of the liver.

\section{Alkaline phosphatase}

The elevation of serum alkaline phosphatase activity in pregnancy is well documented; the bulk of evidence suggests that it arises in the placenta (Boyer, 1961; Birkett, Done, Neale, and Posen, 1966). This evidence cannot explain the frequent increase in serum alkaline phosphatase associated with oestriol or oestradiol administration (Mueller and Kappas, 1964a) and various oestrogen-progestogen combinations (Eisalo et al, 1965; Larsson-Cohn, 1965) which may come from the liver. Kreek, Weser, Sleisenger, and Jeffries (1967c) found a slight rise in the mean value for serum 5 -nucleotidase activity in six women receiving ethynyloestradiol. This enzyme, like alkaline phosphatase, is located in the excretory surface of the liver and has been considered highly specific for hepatic disorders, especially intrahepatic cholestasis(Hill and Sammons, 1967). These observations suggest that the raised alkaline phosphatase level in oestrogen-progestogen administration may be of hepatic origin and may be related to functional alterations involving the hepatic excretory mechanism.

\section{Other enzymes}

The level of serum ornithine transcarbamylase is raised in pregnancy (Reichard, Wigvist, and Yllener, 1961) and during the first month of oral contraceptive therapy (Brohult and Westgren, 1965). The level of serum leucine aminopeptidase is raised in pregnancy (Green, Tsou, Bressler, and Seligman, 1955). This increase is due to at least two isoenzymes ('oxytocinase') arising in the placenta and is not found in patients receiv- ing oestrogen or progestogens (Robinson, $\frac{\rho}{\bar{F}}$ London, and Pierce, 1966). Serum pseudo- $\square$ cholinesterase activity is decreased in pregnancy $\stackrel{\circlearrowright}{F}$ (Pritchard, 1955) as it is in liver disease and may 으․ be due to decreased synthesis. Various oral con- $\overrightarrow{\vec{F}}$ traceptives depress serum cholinesterase activity (Robertson, 1967).

\section{Plasma proteins}

A decrease in total serum protein and albumin has been well documented in pregnancy. Musa, Doe, and Seal (1967) showed a similar but less marked effect after giving oestrogen or oestrogenprogestogen contraceptive tablets. Starch gel electrophoresis of serum from pregnant women shows a zone migrating in the $\alpha 2$-globulin region which is absent in non-pregnant females (Robinson et al, 1966). This 'pregnancy zone' can be produced by administering oestrogen (Musa $e t$ al, 1967) or oestrogen and progestogen (Afonso and de Alvarez, 1963). Fibrinogen levels are increased in pregnancy (Phillips and Skrodellis, 1958) and also by oestrogen-progestogen combinations (Beller and Porges, 1967).

The carrier proteins are increased in pregnancy and during administration of oral contraceptives. Caeruloplasmin levels are increased in pregnancy (Sass-Kortsak, 1965) and also after giving ethynyloestradiol (Musa et al, 1967). Transferrin levels are raised during the latter part of pregnancy (Ventura and Klopper, 1951) but oestrogen treatment does not alter the serum level (Musa et al, 1967). Serum haptoglobin is normal in pregnancy (Nyman, 1959) but is decreased by oestrogen administration (Musa et al, 1967). An increased serum-binding capacity for thyroxine (Dowling, Freinkel, and Ingbar, 1956), cortisol (Slaunwhite and Sandberg, 1959), and testosterone (Pearlman, Crépy, and Murphy, 1967) has been found in pregnancy, presumably indicating increased concentrations of thyroxine-binding globulin, cortisol-binding globulin, and testosteronebinding protein respectively. These proteins increase during pregnancy reaching a maximum during the third trimester. Oestrogen administration can produce an increased serum concentration of thyroxine- and cortisol-binding globulins (Musa, Seal, and Doe, 1965; Musa et al, 1967; Katz and Kappas, 1967) and testosterone-binding protein (Pearlman et al, 1967).

\section{Liver histology}

The administration of 50 to $200 \mathrm{mg}$ oestradiol to patients without liver disease did not produce alterations in the histological appearance of the liver when examined by light microscopy although bromsulphthalein metabolism was impaired (Mueller and Kappas, 1964a). Kleiner et al (1965) did not find any alteration in liver biopsy specimens when examined by light and electron microscopy in normal women who had taken an oral contraceptive preparation for several months. On the other hand, Larsson-Cohn (1967) noted .

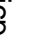
, 
changes in electron microscopy examination of liver biopsy specimens taken from women who had normal liver function tests, using ovulatory suppressants. These changes included dilatation of the canaliculi, shortening or disappearance of microvilli, intracytoplasmic dense bodies, myelin figures, and dilatation of the smooth endoplasmic reticulum.

Some evidence suggests that postmenopausal women are more frequently affected than premenopausal women. Twelve Scandinavian women taking doses usually employed for contraception and four Australian women taking higher doses for the treatment of carcinoma had values between 20 and $40 \%$ for bromsulphthalein retention (Eisalo et al, 1964; Palva and Mustala, 1964; Stoll, Andrews, Motteram, and Upfill, 1965). In most patients the aspartate aminotransferase level was raised to between 200 and 800 units but the alkaline phosphatase level was normal. In five subjects the serum bilirubin level was raised. In all except one case in the carcinoma group the liver tests returned to normal on cessation of therapy.

\section{JAUNDICE ASSOCIATED WITH ORAL} CONTRACEPTIVES

Unless blood and urine tests are done monthly the most obvious pathological alteration of liver function that brings the patient on oral contraceptives to the doctor is the development of jaundice (Fig. 2). This has now been recorded $\cong$ in at least 100 cases. Most of the initial cases were from Scandinavia (eg, Thulin and Nermark, 1966) but reports from England (Baines, 1965), Canada (Elliott and Hendry, 1965), the United States (Boake, Schade, Morrissey, and Schaffner, 1965), and Chile (Orrellana-Alcalde and Domin- $\overline{0}$ guez, 1966) indicate that the syndrome is wide- $\frac{\bar{O}}{\sigma}$ spread.

The case histories are remarkably similar. After taking oral contraceptives for two weeks to several months (usually four weeks or less) the ${ }^{\mathrm{s}}$ subject notices anorexia, malaise, nausea, and $\vec{\circ}$ pruritis. Dark urine and jaundice then appear but $\overrightarrow{\vec{\omega}}$ fever, rash, arthralgias, and severe systemic $\stackrel{\omega}{\omega}$ symptoms are usually absent. Physical examina- $\overrightarrow{0}$ tion is usually unremarkable except for the jaundice and, with the exception of liver function tests, laboratory investigations are unhelpful. $\stackrel{\omega}{-}$ The serum bilirubin is usually in the range 3 to $10 \mathrm{mg} / 100 \mathrm{ml}$ and is mostly conjugated. The 은 aminotransferase levels are increased and values of 1,100 and 1,600 units for the aspartate and alanine aminotransferases respectively may be obtained. The possibility of viral hepatitis with these high levels can be excluded by the study of liver biopsies (Thulin and Nermark, 1966). Histo- $\mathscr{\mathscr { C }}$ logical examination shows canalicular and hepato- $\odot$ cellular bile stasis, generally slight, but a variable degree of hepatocellular degeneration and necrosis with minimal or absent inflammatory reaction. Hepatocellular damage, if present, is

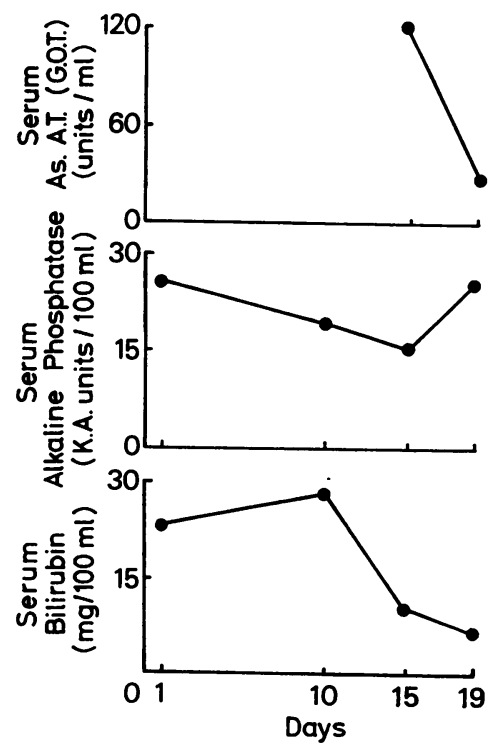

Fig. 2 Diagram of the course of jaundice due to Ovulen in a 36-year-old woman.

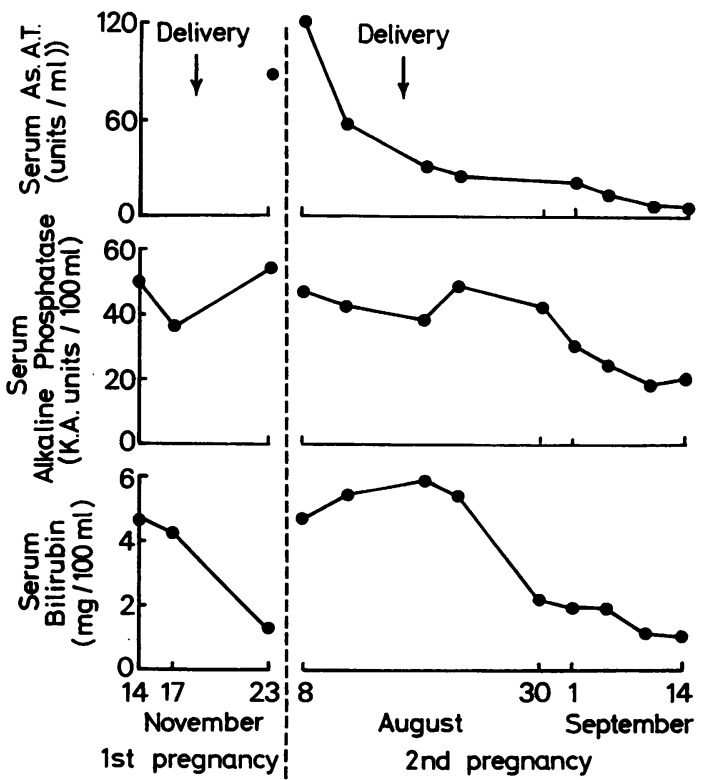

Fig. 3 Diagram of the progress of cholestatic jaundice of pregnancy in a 32-year-old woman. 
limited to centrilobular areas (Stoll et al, 1965). Electron microscopy of the liver shows changes similar to other types of intrahepatic cholestasis with dilatation of bile canaliculi, bile stasis, shortening and blunting of microvilli, and dilatation of the endoplasmic reticulum which often lacks ribosomes (Boake et al, 1965; Larsson-Cohn and Stenram, 1965).

Schaffner (1966) has suggested that oral contraceptives may cause jaundice with hypersensitivity features as well as an intrahepatic cholestatic type of jaundice because of the occurrence of eosinophilia and tissue reactions such as erythema nodosum. Other features recorded in at least two cases of jaundice due to oral contraceptives include urticaria, joint pains, and fever.

Cessation of oral contraceptive therapy usually results in complete chemical and clinical remission within a few weeks or a few months. Rarely the abnormal liver tests may persist for a long period (Boake et al, 1965). In two cases the contraceptives were readministered after remission and the jaundice recurred (Adlercreutz and Ikonen, 1964; Thulin and Nermark, 1966). A number of women in whom jaundice due to oral contraceptives occurred had previously developed cholestatic jaundice or pruritis of pregnancy.

The disturbed liver function occurring in some patients taking oral contraceptives resembles the changes observed in late pregnancy when hepatic excretory function is disturbed. If this is severe then the patients become frankly jaundiced, usually with each pregnancy. This has been called 'intrahepatic cholestasis of pregnancy' and is a clinical entity, occurring in late pregnancy, characterized by jaundice, pruritis, and bromsulphthalein retention (Fig. 3). The similarity between this type of jaundice and that due to oral contraceptives is striking. In both conditions there are a minimum of systemic manifestations; the jaundice is due to conjugated bilirubin, and on removal of the offending steroids, ie, ceasing therapy or parturition, remission occurs. Liver biopsy in patients with intrahepatic cholestasis of pregnancy shows intrahepatic cholestasis indistinguishable from the histological appearances of oral-contraceptive-induced jaundice (Brown, Porta, and Reder, 1963). Administration of oral contraceptives to these patients precipitates intrahepatic cholestasis (Boake et al, 1965). These observations show that the normal response of the liver to an increased load of certain steroids, such as occurs in late pregnancy or with oral contraceptives, is a mild alteration of certain hepatic excretory functions, especially the excretion of bromsulphthalein; this effect on the liver resembles that produced by certain anabolic steroids. The response takes a more severe form in a few women in whom intrahepatic cholestasis presenting as recurrent jaundice of pregnancy or jaundice due to oral contraceptives occurs. The reasons for this are not known.

In a few women, therefore, oral contraceptives produce jaundice associated with reversible noninflammatory intrahepatic cholestasis. Although it is possible that increased awareness may result in more frequent case reports, hepatic dysfunction is rare in relation to the large number of women taking the drugs.

\section{Contraindications to Administration}

Since oral contraceptives may adversely affect liver function certain limitations in the use of these agents are indicated. A history of intrahepatic cholestasis of pregnancy is a contraindication because of the apparent connexion between this and jaundice due to oral contraceptives. The situation is less clear with regard to other situations. The American Medical Association (Committee on Human Reproduction; The Control of Fertility, 1965) suggests the drugs are contraindicated in patients with either a reliable history or presence of hepatic disease or dysfunction. The World Health Organisation (1966) states that "cirrhosis and viral hepatitis do not appear to be aggravated by these agents'. In general it is recommended that alternative methods of contraception be used in patients with acute and chronic disturbance of liver function whether congenital or acquired. If there is a history of acute liver disease in the past then the drugs may be given if there is no evidence of activity at the time of treatment.

The onset of pruritis or upper gastrointestinal tract symptoms after the first few cycles should suggest the possibility of hepatic dysfunction. Evidence of mild bromsulphthalein retention is not sufficient evidence to stop the drug. Some physicians stop the drug if there are raised aminotransferase levels but as mentioned before there is evidence that these fall on continued administration of the drug.

\section{Pathogenesis}

Oral contraceptives can cause disturbed liver function in some patients resembling the changes seen in late pregnancy. The mechanism of these changes is not yet known but the evidence can be reviewed by considering the action of oestrogens and progestogens on cholephil excretion, glucuronyltransferase, and on other liver enzymes.

\section{CHOLEPHIL EXCRETION}

Hepatic parenchymal cells have the ability to take up and secrete a number of substances into bile at concentrations far exceeding their plasma concentration. We have designated these substances 'cholephils' (Hargreaves and Lathe, 1963). They include bilirubin, bile acids, certain organic 
dyes such as bromsulphthalein, indocyanine green, and rose bengal; antibiotics such as novobiocin and methicillin; and steroid hormones. In general the rate of clearance of endogenous and exogenous cholephils depends on the uptake into liver cells, metabolic conversion in the cells, and secretion into bile canaliculi.

A number of workers have shown that the standard bromsulphthalein retention test is impaired in some women taking oral contraceptives (Eisalo et al, 1965; Larsson-Cohn, 1965). The incidence of this abnormality appears to be related in part to the dose of oral contraceptives (Allan and Tyler, 1967).

It is not yet clear whether the oestrogenic or progestogenic component of oral contraceptive tablets causes the impairment of hepatic function. Evidence that the oestrogenic component may be primarily responsible for the disturbance includes the observations of Adlercreutz and Ikonen (1964) that jaundice occurred in a woman with a history of cholestatic jaundice of pregnancy when she was taking norethynodrel and mestranol. The jaundice was subsequently produced with lynestrenol and mestranol but not with lynestrenol (the progestational agent) alone. Eisalo et al (1964) found that hepatic abnormalities produced in a group of postmenopausal women by lynestrenol and mestranol could be produced by mestranol (oestrogen) alone but not with lynestrenol. Kreek et al (1967c) suggested that ethynyloestradiol could cause hepatic impairment while Urban, Frank, and Kern (1968) found liver dysfunction with mestranol but not with norethynodrel in a patient with jaundice due to Enovid.

Oestriol and oestradiol, when given to human subjects in doses approximating to those produced in late pregnancy, induce bromsulphthalein retention (Mueller and Kappas, 1964a, b). Utilizing constant infusion techniques there was a decrease in the maximum hepatic transport (Tm) of the dye without a change in storage capacity for the dye. Multiple sampling after a single injection of bromsulphthalein in oestrogentreated women showed that transfer of the dye from the liver cells to the bile was impaired (Kottra and Kappas, 1967). The appearance of excessive amounts of conjugated bromsulphthalein in plasma during oestrogen treatment is consistent with an increase in the rate of reflux of the dye back into plasma from the liver as observed in pregnancy.

Gallagher, Mueller, and Kappas (1960) examined the effects of a variety of natural and synthetic steroids on bromsulphthalein metabolism in the rat. Ten days' treatment with oestradiol and its metabolites, including oestrone and oestriol, produced impaired hepatic disposal of bromsulphthalein. Oestradiol did not alter the hepatic glutathione content or the bromsulphthalein-glutathione conjugating activity. Other steroids such as testosterone, progesterone, cortisol, and bile acids did not alter bromsulph $\frac{\rho}{\overline{5}}$ thalein metabolism. Kreek, Peterson, Sleisengerp and Jeffries (1967a) showed that rats treated wit: ethynyloestradiol have a delayed clearance of bromsulphthalein, decreased bile flow, and de creased biliary excretion of the administeres oestrogen.

Forker (1969) gave rats large doses of oestron and showed that they developed increase 8 permeability of the biliary tree as determined bi an increase in the biliary clearance of sucrose an $\$$ mannitol. Oestrone reduced spontaneous bile. flow and the choleretic response to dehydro cholate. On the basis of these experiments, and the finding that the clearance and absolute rate ơ bromsulphthalein excretion were reduced, he suggested that oestrogen cholestasis may involv enhanced diffusion of materials from bile $t \&$ blood in addition to inhibition of active transport in the opposite direction.

There is some evidence that the progestogem component may cause hepatic impairment. Marquardt, Fisher, Levy, and Dowben (1961ఖ showed that norethynodrel caused bromsulph thalein retention. Stoll, Andrews, and Motteran (1966) showed that administration of lynestrenoto the progestogen component of Lyndiol, was assog ciated with raised aspartate aminotransferase levels and with hepatocanalicular damage demono strated by liver biopsy. Mestranol, the estrogets component of Lyndiol, caused no abnormality Kleiner et al (1965) determined the maximung transport rate $(\mathrm{Tm})$ and the storage capacity $(\mathbf{S} \propto$ for bromsulphthalein in a group of women taking an oral contraceptive preparation containing norethynodrel and mestranol at ovulation-sup pressing doses. After several months of cyclic op continuous treatment the mean hepatic transpors maximum (Tm) was reduced from 31 to $60 \%$ of the value in normal controls while the storage capacit 8 was unaffected. In two patients in whom the drug was withdrawn the Tm returned to normal with? in seven days of stopping the drug. Because this effect was not produced by equivalent doses of oestradiol alone they concluded that the progesta tional steroid (norethynodrel) was responsible for: the effect. It is possible that the infusion test wilts detect more abnormalities in women receiving orah contraceptives than the standard bromsulph요 thalein test. Progesterone does not impair brom sulphthalein excretion in laboratory animalse (Gallagher $e t$ al, 1960) or in patients (Mueller an\& Kappas, 1964a). It is difficult to draw conclusions from the available evidence. A number of workers have shown that oestrogens in high doses impaif hepatic excretory functions. The evidence about progestogens is less definite although it seems a though these substances can also impair hepatie excretion.

The disturbed liver function observed in some patients taking oral contraceptives resembles the changes observed in late pregnancy. Using the conventional bromsulphthalein test, whict 
measures the retention of dye 45 minutes afier giving a single intravenous dose of a fixed amount of dye, the mean values are slightly higher than normal in pregnant women (Combes, Shibata, Adams, Mitchell, and Trammell, 1963; Tindall and Beazley, 1965). Blood flow through the liver is unchanged during pregnancy (Munnell and Taylor, 1947). Infusion of cholephils, such as bromsulphthalein, and the determination of other parameters has increased our knowledge of hepatic transport in pregnancy. In 1933 Soffer showed that the plasma clearance of an infused load of bilirubin was delayed in women in the latter half of gestation. Combes et al (1963), using the constant infusion technique of Wheeler, Meltzer, and Bradley (1960), showed a mean increase of $122 \%$ in the relative hepatic storage capacity for bromsulphthalein and a consistent and significant decrease in the maximum transport rate $(\mathrm{Tm})$ for dye excretion into the bile. The mean value for $\mathrm{Tm}$ in nonpregnant women was 8.5 $\mathrm{mg} / \mathrm{min}$ whereas in the latter half of pregnancy it was $6.7 \mathrm{mg} / \mathrm{min}$. Tindall and Beazley (1965) used a compartmental analysis of plasma after a single intravenous injection of bromsulphthalein in pregnant women (Richards, Tindall, and Young, 1959). These authors found a slight increase in the rate of hepatic uptake of bromsulphthalein, a reduction in the rate of excretion of the dye from the liver cell to the bile, and an increased rate of reflux of dye into the plasma. These studies, although measuring different functions, indicate that pregnancy is associated with a significant impairment of the excretory capacity of the liver for bromsulphthalein which occurs at saturating and nonsaturating concentrations of the dye in the liver. The excretory capacity returns to a normal level rapidly after delivery.

When hepatic excretory capacity is severely impaired in pregnancy then the patient develops intrahepatic cholestasis of pregnancy. Adlercreutz, Svanborg, and Ånberg (1967) studied a young woman with a history of recurrent cholestasis of pregnancy and showed that between the sixth and eighth months of pregnancy the concentration of conjugated oestradiol, oestrone, and oestriol in bile (obtained by duodenal intubation) decreased even though she was not icteric, suggesting impaired hepatic excretion of steroids despite the continued capacity of the liver to dispose of bilirubin in an apparently normal manner. With the subsequent development of jaundice the biliary concentration of oestrogens decreased further. Kater, Harrison, and Mistilis (1967), using an abridged modification of Wheeler's method, showed that in 13 patients with intrahepatic cholestasis of pregnancy there was a significant diminution of relative storage capacity and maximum hepatic transport of bromsulphthalein.

A hormonal basis for the pathogenesis of intrahepatic cholestasis of pregnancy has been repeatedly suggested. The characteristic onset during late pregnancy and the subsidence of all signs upon termination has a correlation with the extent of maternal exposure to endogenously produced oestrogens and progestogens. It has been noted that a number of patients who have jaundice due to oral contraceptives have previously had cholestatic jaundice of pregnancy; in the series of 23 patients reported by Haemmerli and Wyss (1967) it was more than $50 \%$. This is more impressive when considering that the incidence of jaundice in pregnancy is less than $0.1 \%$ (Haemmerli, 1966). When patients with a known history of cholestatic jaundice of pregnancy were given oral contraceptives (Boake et al, 1965) or a synthetic oestrogen (Kreek, Sleisenger, and Jeffries, 1967b; Kreek et al, 1967c) they developed the signs, symptoms, and laboratory findings of intrahepatic cholestasis which subsided when the drugs were withdrawn. Although the evidence is still circumstantial it seems as though the liver changes of late gestation are related to those seen with the administration of oral contraceptives.

\section{GLUCURONYL TRANSFERASE}

Progestational agents have been shown to have an effect on glucuronyl transferase, the enzyme conjugating bilirubin with uridine 5 '-pyrophosphate glucuronic acid (UDPGA). Lathe and Walker (1958) showed that formation of bilirubin glucuronide by rat liver slices was inhibited by sera from pregnant women, cord blood, and blood from newborn infants added to the incubation medium. A variety of steroids, including progestational steroids, inhibit conjugation in the same system (Lathe and Walker, 1958) and in liver broken cell or microsomal preparations (Hsia, Dowben, Shaw, and Grossman, 1960; Hsia, Dowben, and Riabov, 1963; Hsia, Riabov, and Dowben, 1963). The effect of pregnanediol and its glucuronide on conjugation has been the subject of several conflicting reports but it seems to depend on the concentration of drugs employed (see Hargreaves, 1968). Oestrone, oestradiol, and oestriol do not inhibit bilirubin conjugation in rat liver slices (Lathe and Walker, 1958).

We have attempted to relate these effects to the cholestatic jaundice of pregnancy by examining the effect of serum from such a patient on the conjugation of $o$-aminophenol in rat liver slices. There was no greater effect on conjugation than a comparable non-jaundiced maternal serum, suggesting that in this case there was no excess of a circulating inhibitor of conjugation.

OTHER LIVER ENZYMES

The effect of oral contraceptives on a number of other liver enzymes has been examined. These effects of oral contraceptives should be realized by all who prescribe the drugs. It is becoming 
increasingly apparent that continuous administration of oral contraceptives interferes with the metabolism of other drugs, for example, the effect of diphenylhydantoin on dexamethazone (Werk, Choi, Sholiton, Olinger, and Haque, 1969). In the case of oral contraceptives we are condemning young women to years of drug therapy without adequate knowledge of their long-term effects.

The effect of oestrogens and progestogens on the hepatic oxidative metabolism of drugs seems to depend on the experimental methods employed. Tephly and Mannering (1968) have shown that both oestradiol and progesterone, together with a number of other steroids, are competitive inhibitors of microsomal oxidases for ethylmorphine and hexobarbitone in the rat. Schenkman, Remmer, and Estabrook (1967) have shown that oestradiol and a number of other drugs, including hexobarbitone, interact with microsomal cytochrome P 450. Continuous treatment of rats with progesterone decreases the capacity of the liver to metabolize various phosphothionates (Murphy and DuBois, 1958) but does not influence hexobarbitone metabolism in vitro (Juchau and Fouts, 1966). Norethynodrel, however, induces a significant enhancement of the metabolism of hexobarbitone in vitro. These authors also found that treatment with norethynodrel and mestranol resulted in a significant reduction in the rate of hexobarbitone metabolism.

It is not certain whether these changes are related to an increase in the amount of microsomal oxidase which is known to be produced after the administration of certain other drugs (Conney, 1967). Shortening of the duration of action of barbiturates is considered to be indicative of an increase in the level of enzymes that inactivate them whereas enzyme inhibition, on the other hand, will increase the duration of action.

Glock and McLean (1953) noted that the activity of glucose 6-phosphate dehydrogenase was twice as high in female rats compared with males. The administration of oestradiol to castrated male rats increases the activity by twoto fourfold (Huggins and Yao, 1959). This can be prevented by puromycin (Hori and Matsui, 1967). The increase is in one specific isoenzyme fraction (fraction D) which is increased in females and after oestrogen administration. Dehydroepiandrosterone decreases the concentration of this isoenzyme, suggesting that oestrogen may play a part in glucose 6-phosphate dehydrogenase synthesis.

Oestrogens also increase $\delta$-aminolaevulinic acid synthetase. Increased amounts of this enzyme occur in porphyria, especially in intermittent acute porphyria. Since females tend to be affected predominantly and the condition tends to relapse in pregnancy, it was suggested that the disease may be influenced by sex hormones. This has been shown experimentally by the demon- stration that oestradiol and progesterone and some of their metabolites stimulate porphyrint production in chick embryo liver cells growing in primary culture (Kappas and Granick, 1968).을 This mechanism involves synthesis de novo of $\delta$-aminolaevulinic acid synthetase. Stimulation? of the enzyme also occurs in embryonic erythroido cells (Levere, Kappas, and Granick, 1967) but the most potent inducers are hormone precursors rather than the hormones themselves. Recently@ Tschudy, Waxman, and Collins (1967) haves shown that $4 \mu \mathrm{g}$ of oestradiol reduced the hepaticactivity of $\delta$-aminolaevulinic acid synthetase followed by an increase in activity, suggesting $\vec{\omega}$ that it acts as an inhibitor of breakdown rather than a stimulator of its synthesis.

The evidence suggests that oestrogens andes progestogens can increase the activity of certain $\overrightarrow{\dot{\omega}}$ liver enzymes. The effect of the steroids used inoral contraceptives should be determined on these and other liver enzymes so that the effects of long-term administration of oral contraceptives in human subjects can be evaluated.

It is well known that pregnancy in animals? increases liver weight but this has never been adequately confirmed in human subjects. In $\overrightarrow{0}$ animals repeated doses of oestrogens (Gallaghero et al, 1960) and progesterone (Hines, 1967) will increase liver weight. A single dose of oestrogeno will not, however, increase liver weight s (Thompson, Severson, and Reilly, 1966) althoughō it will induce rapid uterine growth. The RNA응 content of liver is greatly increased in rats during $\varrho$ pregnancy (Campbell and Kosterlitz, 1953), the $\overrightarrow{\vec{*}}$ increase exceeding the increase observed for 3 protein. It seems as though oestrogen is responsible for this increase since oestradiol but not? progesterone administered to male rats increases liver RNA (Campbell, Innes, and Kosterlitz, 1953) when administered repeatedly for 10 to 143 days. The rate of incorporation of $\left[1-{ }^{14} \mathrm{C}\right]$ glycine (Burt and Dannenburg, 1965) and $\left[1{ }^{14} \mathrm{C}\right]$ valine $\mathrm{O}$ (Little and Lincoln, 1964) is accelerated in pregnant rats. A single dose of oestradiol $(2 \mu \mathrm{g}) \stackrel{\circ}{-}$ which increases the incorporation of $\left.\left[1-{ }^{14} \mathrm{C}\right]\right]_{0}$ valine into uterine protein does not affect the rate of protein synthesis in the liver. There appears to be no record of the effest of progesterone on protein metabolism.

I wish to thank Dr J. H. Simpson and Mr P. M. G. Russell for permission to publish cases admitted under $\mathbb{\mathscr { D }}$ their care. I also wish to thank the South West ${ }^{-}$ Regional Hospital Board for financial assistance.

References

Adlercreutz, H., and Ikonen, E. (1964). Oral contraceptives and liver damage. Brit. med. J., 2, 1133.

Adlercreutz, H., Svanborg, Å., and Ånberg, A. (1967). Recurrento jaundice in pregnancy. II. A study of the estrogens and their conjugation in late pregnancy. Amer. J. Med., $426 \overline{\mathrm{Q}}$ 341-347. 
Afonso, J. F., and de Alvarez, R. R. (1963). Further starch gel fractionation of new protein zones in pregnancy. Amer. $J$. Obstet. Gynec., 86, 815-819.

Allan, J. S., and Tyler, E. T. (1967). Biochemical findings in longterm oral contraceptive usage. I. Liver function studies. Fertil. and Steril., 18, 112-123.

American Medical Association. Committee on Human Reproduction (1965). The control of fertility. J. Amer. med. Ass., 194, 462-470.

Baines, G. F. (1965). Jaundice in a patient taking norethisterone compound tablets. Lancet, 1, 108-109.

Beller, F. K., and Porges, R. F. (1967). Blood coagulation and fibrinolytic enzyme studies during cyclic and continuous application of progestational agents. Amer. J. Obstet. Gynec., 97, 448-459.

Birkett, D. J., Done, J., Neale, F. C., and Posen, S. (1966). Serum alkaline phosphatase in pregnancy: an immunological study. Brit. med. J., 1, 1210-1211.

Boake, W. C., Schade, S. G., Morrissey, J. F., and Schaffner, F. (1965). Intrahepatic cholestatic jaundice of pregnancy followed by Enovid-induced cholestatic jaundice. Report of a case. Ann. intern. Med., 63, 302-308.

Borglin, N. E. (1965). Oral contraceptives and liver damage. Brit. med. J., 1, 1289-1290.

Boyer, S. H. (1961). Alkaline phosphatase in human sera and placentae. Science, 134, 1002-1004.

Brohult, J., and Westgren, A. (1965). Liver metabolism and contraceptive steroids. Lancet, 2, 1344.

Brown, D. F., Porta, E. A., and Reder, J. (1963). Idıopathic jaundice of pregnancy. Arch. intern. Med., 111, 592-606.

Burt, R. L., and Dannenburg, W. N. (1965). The effect of pregnancy on glycine-1-14 $\mathrm{C}$ incorporation in liver protein of the rat. Acta endocr. (Kbh.), 50, 643-647.

Campbell, R. M., and Kosterlitz, H. W. (1953). Species differences in the deoxyribonucleic and ribonucleic acid contents of livers of non-pregnant and pregnant mice, guinea-pigs and cats. J. Endocr., 9, 45-51.

Campbell, R. M., Innes, I. R., and Kosterlitz, H. W. (1953). The role of hormonal and dietary factors in the formation of excess ribonucleic acid in the livers of pregnant rats. J. Endocr., 9, 52-67.

Combes, B., Shibata, H., Adams, R., Mitchell, B. D., and Trammell, V. (1963). Alterations in sulfobromopthalein sodium-removal mechanisms from blood during normal pregnancy. $J$. clin. Invest., 42, 1431-1442.

Conney, A. H. (1967). Pharmacological implications of microsomal enzyme induction. Pharmacol. Rev., 19, 317-366.

Cullberg, G., Lundström, R., and Stenram, U. (1965). Jaundice during treatment with an oral contraceptive, lyndiol. Brit. med. J., 1, 695-697.

Dowling, J. T., Freinkel, N., and Ingbar, S. H. (1956). Effect of diethylstilbestrol on the binding of thyroxine in serum. J. clin. Endocr., 16, 1491-1506.

Elliott, A. J., and Hendry, J. (1965). Cholestatic jaundice complicating pregnancy: recurrence after norethynodrel with ethynylestradiol (ENOVID). Canad. med. Ass. J., 92, 344-345.

Eisalo, A., Järvinen, P. A., and Luukkainen, T. (1964). Hepatic impairment during the intake of contraceptive pills: clinical trial with post menopausal women. Brit. med. J., 2, 426-427.

Eisalo, A., and Räsänen, J. (1965). Jaundice during intake of oral contraceptive, Lyndiol. Ann. Med. intern, Fenn., 54, 47-49.

Eisalo, A., Järvinen, P. A., and Luukkainen, T. (1965). Liverfunction tests during intake of contraceptive tablets in pre-menopausal women. Brit. med. J., 1, 1416-1417.

Forker, E. L. (1969). The effect of estrogen on bile formation in the rat. J. clin. Invest., 48, 654-663.

Gallagher, T. F. Jr., Mueller, M. N., and Kappas, A. (1960). Estrogen pharmacology. IV. Studies on the structural basis for estrogen-induced impairment of liver function. Medicine (Baltimore), 45, 471-479.

Glock, G. E., and McLean, P. (1953). Further studies on the properties and assay of glucose 6-phosphate dehydrogenase and 6-phosphogluconate dehydrogenase of rat liver. Biochem. J., 55, 400-408.

Goldzieher, J. W. (1964). Newer drugs in oral contraception. Med Clin. N. Amer., 48, 529-545.

Green, M. N., Tsou, K. C., Bressler, R., and Seligman, A. M. (1955). The colorimetric determination of leucine aminopeptidase activity with L-leucyl- $\beta$-napthylamide hydrochloride. Arch. Biochem., 57, 458-474.

Haemmerli, U. P. (1966). Jaundice during pregnancy. Acta. med. scand., 104, suppl. 444.

Haemmerli, U. P., and Wyss, H. I. (1967). Recurrent intrahepatic cholestasis of pregnancy, report of six cases and review of the literature. Medicine (Baltimore), 46, 299-321.

Hargreaves, T., and Lathe, G. H. (1963). Inhibitory aspects of bile secretion. Nature (Lond.). 200. 1172-1176
Hargreaves, T. (1968). The Liver and Bile Metabolism, p. 377. Appleton Century Crofts, New York.

Hartley, R. A., Boitnott, J. K., and Iber, F. L. (1969). Topics in clinical medicine. The liver and oral contraceptives. Johns Hopk. med. J., 124, 112-118.

Hill, P. G., and Sammons, H. G. (1967). An assessment of $5^{\prime}$-nucleotidase as a liver-function test. Quart. J. Med., $36,457-468$.

Hines, W. J. (1967). Enlargement of liver in rats after chronic administration of flumedroxone acetate. J. Pharmacol. 19, 126-127.

Hsia, D. Y. Y., Dowben, R. M., and Riabov, S. (1963). Inhibitors of glucuronyl-transferase in the newborn. Ann. N.Y. Acad. Sci., 111, 326-336.

Hsia, D. Y. Y., Dowben, R. M., Shaw, R., and Grossman, A. (1960). Inhibition of glucoronosyl transferase by progestational agents from serum of pregnant women. Nature (Lond.), 187, 693-694.

Hsia, D. Y. Y., Riabov, S., and Dowben, R. M. (1963). Inhibition of glucuronosyl transferase by steroid hormones. Arch. Biochem., 103, 181-185.

Hori, S. H., and Matsui, S. I. (1967). Effects of hormones on hepatic glucose 6-phosphate dehydrogenase of rat. $J$ Histochem. Cytochem., 15, 530-534.

Huggins, C., and Yao, F. (1959). Influence of hormones on liver. I. Effect of steroids and thyroxine on pyridine nucleotidelinked dehydrogenases. J. exp. Med., 110, 899-919.

Juchau, M. R., and Fouts, J. R. (1966). Effects of norethynodrel and progesterone on hepatic microsomal drug-metabolizing enzyme systems. Biochem. Pharmacol., 15, 891-898.

Kappas, A., and Granick, S. (1968). Steroid induction of porphyrin synthesis in liver cell culture. II. The effects of heme, uridine diphosphate glucuronic acid, and inhibitors of nucleic acid and protein synthesis on the induction process. J. biol. Chem., 243, 346-351.

Kater, R. M. H., Harrison, D. D., and Mistilis, S. P. (1967) Alterations in sulfobromophthalein sodium removal from blood in patients with pruritus of pregnancy. Gastroenterology, 53, 941-946.

Katz, F. H., and Kappas, A. (1967). The effects of estradiol and estriol on plasma levels of cortisol and thyroid hormone binding globulins and on aldosterone and cort isol secretion rates in man. $J$. clin. Invest., 46, 1768-1777.

Kleiner, G. J., Kresch, L., and Arias, I. M. (1965). Studies of hepatic excretory function. II. The effect of norethynodrel and mestranol on bromsulfalein sodium metabolism in women of childbearing age. New Engl. J. Med., 273, 420-423.

Kottra, J., and Kappas, A. (1967). Steroid effects on hepatic function: recent observations. Ann. Rev. Med., 18, 325-332.

Kreek, M. J., Peterson, R. E., Sleisenger, M. H., and Jeffries, G. H. (1967a). Influence of ethinyl estradiol-induced cholestasis on bile flow and biliary excretion of estradiol and bromsulfopthalein by the rat. J. clin. Invest., 46 , 1080.

Kreek, M. J., Sleisenger, M. H., and Jeffries, G. H. (1967b) Recurrent cholestatic jaundice of pregnancy with demonstrated estrogen sensitivity. Amer. J. Med., 43, 795-803.

Kreek, M. J., Weser, E., Sleisenger, M. H., and Jeffries, G. H. (1967c). Idiopathic cholestasis of pregnancy. The response to challenge with the synthetic estrogen, ethinylestradiol. New Engl. J. Med., 277, 1391-1395.

Larsson-Cohn, U. (1965). Oral contraception and liver function tests. Brit. med. J., 1, 1414-1415.

Larsson-Cohn, U. (1966). An appraisal of the clinical effect of three different oral contraceptive agents and their influence on transaminase activity. Acta obstet. gynec. scand., 45, 499-514.

Larsson-Cohn, U. (1967). 'Contraceptive pills today.' Laekartidningen (Swedish), 64, 2566-2572.

Larsson-Cohn, U., and Stenram, U. (1965). Jaundice during treatment with oral contraceptive agents: report of two cases. J. Amer. med Ass., 193, 422-426.

Lathe, G. H., and Walker, M. (1958). Inhibition of bilirubin conjugation in rat liver slices by human pregnancy and neonatal serum and steroids. Quart. J. exp. Physiol., 43, 257-265.

Levere, R. D., Kappas, A., and Granick, S. (1967). Stimulation of hemoglobin synthesis in chick blastoderms by certain $5 \beta$ androstane and $5 \beta$ pregnane steroids. Proc. nat. Acad. Sci. (Wash.), 58, 985-990.

Little, B., and Lincoln, E. (1964). Effect of estrogen, progesterone and testosterone on the incorporation of L-Valine-1-C 14 into protein of the rat liver and uterus. Endocrinology, 74, 1-8.

Marquardt, G. H., Fisher, C. I., Levy, P., and Dowben, R. M. (1961). Effect of anabolic steroids on liver function tests and creatine excretion. J. Amer. med. Ass., 175, 851-853. 
Mueller, M. N., and Kappas, A. (1964a). Estrogen pharmacology. I. The influence of estradiol and estriol on hepatic disposal of sulphobromophthalein (BSP) in man. J. clin. Invest., 43, 1905-1914.

Mueller, M. N., and Kappas, A. (1964b). Impairment of hepatic excretion of sulfobromophthalein (BSP) by natural estrogens. Trans. Ass. Amer. Phycns, 77, 248-258.

Munnell, E. W., and Taylor, H. C., Jr. (1947). Liver blood flow in pregnancy: hepatic vein catheterization. J. clin. Invest., 26, 952-956.

Murphy, S. D., and DuBois, K. P. (1958). The influence of various factors on the enzymatic conversion of organic thiophosphates to anticholinesterase agents. J. Pharmacol. exp. Ther., 124, 194-202.

Musa, B. U., Seal, U. S., and Doe, R. P. (1965). Elevation of certain plasma proteins in man following estrogen administration: a dose-response relationship. J. clin. Endocr., 25, 1163-1166.

Musa, B. U., Doe, R. P., and Seal, U. S. (1967). Serum protein alterations produced in women by synthetic estrogens. J. clin. Endocr., 27, 1463-1469.

Nyman, M. (1959). Serum haptoglobin: methodological and clinical studies. Scand. J. clin. Lab. Invest., 11, suppl. 39.

Orellana-Alcalde, J. M., and Dominguez, J. P. (1966). Jaundice and oral contraceptive drugs. Lancet, $2,1278-1280$.

Palva, I. P., and Mustala, O. O. (1964). Oral contraceptives and liver damage. Brit. med. J., 2, 688-689.

Pearlman, W. H., Crépy, O., and Murphy, M. (1967). Testosteronebinding levels in the serum of women during the normal menstrual cycle, pregnancy and the post-partum period. J. clin. Endocr., 27, 1012-1018.

Perez-Mera, R. A., and Shields, C. E. (1962). Jaundice associated with norethindrone acetate therapy. New Engl. J. Med., 267, 1137-1138.

Phillips, L. L., and Skrodelis, V. (1958). The fibronolytic enzyme system in normal, hemorrhagic and disease states. J. clin. Invest., 37, 965-973.

Pritchard, J. A. (1955). Plasma cholinesterase activity in normal pregnancy and in eclamptogenic toxemias. Amer. J. Obstet. Gynec., 70, 1083-1086.

Reichard, H., Wigvist, N., and Yllner, S. (1961). Serum ornithine carbamyl transferase activity in normal pregnancy and in pregrancy complicated by pruritus. Acta obstet. gynec. scand., 40, 244-251.

Rice-Wray, E. (1964). Oral contraceptives and liver damage. Brit. med. J., 2, 1011.

Richards, T. G., Tindall, V. R., and Young, A. (1959). A modification of the bromsulphthalein liver function test to predict the dye content of the liver and bile. Clin. Sci., $18,499-511$.

Robertson, G. S. (1967). Serum protein and cholinesterase changes in association with contraceptive pills. Lancet, 1, 232-235.

Robinson, J. C., London, W. T., and Pierce, J. E. (1966). Observations on the origin of pregnancy-associated plasma proteins. Amer. J. Obstet. Gynec., 96, 226-230.

Sass-Kortsak, A. (1965). Copper metabolism. Advanc. clin. Chem. $8,1-67$.

Schaffner, F. (1966). The effect of oral contraceptives on the liver. J. Amer. med. Ass., 198, 1019-1021.

Schenkman, J. B., Remmer, H., and Estabrook, R. W. (1967) Spectral studies of drug interaction with hepatic microsomal cytochrome. Mol. Pharmacol., 3, 113-123.

Slaunwhite, W. R. Jr., and Sandberg, A. A. (1959). Transcortin: a corticosteroid-binding protein of plasma. J. clin. Invest., 38, 384-391.

Soffer, L. J. (1933). Bilirubin excretion test as a test for liver function during normal pregnancy. Bull. Johns. Hopk. Hosp., 52, 365-375.

Sotaniemi, E., Kreus, K. E., and Scheinin, T. M. (1964). Oral contraception and liver damage. Brit. med. J., 2, 1264-1265.

Stoll, B. A., Andrews, J. T., Motteram, R., and Upfill, J. (1965)

Oral contraceptives and liver damage. Brit. med. J., 1, 723.

Stoll, B. A., Andrews, J. T., and Motteram, R. (1966). Liver damage from oral contraceptives. Brit, med. $J$. 1, 960-961.

Swaab, L. I. (1964). Oral contraceptives and liver damage. Brit. med. J., $2,755$.

Swver, G. I. M., and Little, V. (1965). Absence of hepatic impairment in long-term oral-contraceptive users. Brit. med. $J$., 1, 1412-1415.

Tephly, T. R., and Mannering, G. J. (1968). Inhibition of drug metabolism. V. Inhibition of drug metabolism by steroids. Mol. Pharmacol., 4, 10-14.

Thompson, J. S., Severson, C. D., and Reilly, R. W. (1966). The effect of estradiol and irradiation on the nucleic acid metabolism of the thymus, spleen, lymph node, and liver of mice. Radiation Res., 29, 537-548.

Thulin, K. E., and Nermark, J. (1966). Seven cases of jaundice in women taking an oral contraceptive, Anovlar. Brit. med. J., 1, 584-586,
Tindall, V. R., and Beazley, J. M. (1965). An assessment of changet during ncrmal pregnancy-using a modified brom? sulphthalein test. J. Obstet. Gynaec. Brit. Cwlth, 72, 717 D 737.

Tschudy, D. P., Waxman, A., and Collins, A. (1967). Oscillation of hepatic $\delta$-aminolevulinic acid synthesis produced by. estrogen: a possible role of 'rebound induction' in' biological clock mechanisms. Proc. nat. Acad. Sci. (Wash. 58, 1944-1948.

Urban, E., Frank, B. W., and Kern, F., Jr. (1968). Liver dy? function with mestranol but not with norethynodrel in patient with Enovid-induced jaundice. Ann. intern. Med $\overline{\bar{n}}$ 68, 598-602.

Ventura, S., and Klopper, A. (1951). Iron metabolism in preg nancy. J. Obstet. Gynaec. Brit. Cwlth, 58, 173-189.

Werk, E. E., Jr., Choi, Y., Sholiton, L., Olinger, C., and Haquê, $N$. (1969). Interference in the effect of dexamethasone by diphenylhydantoin. New Engl. J. Med., 281, 32-34.

Wheeler, H. O., Meltzer, J. I., and Bradley, S. E. (1960). Biliary transport and hepatic storage of sulphobromophthaleie

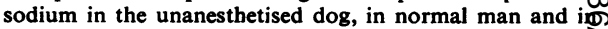
patients with hepatic disease. J. clin. Invest., 39, 1131-1144

World Health Organization (1966). Clinical aspects of orat gestogens. Tech. Rep. WHO, no. 326, 12-13 